\title{
Effect of Dietary Inclusion of Citric Acid with Phytase as Supplement on Growth Responses of Rainbow Trout
}

\author{
Suraj Kumar Singh ${ }^{1, a, *}$, Mahendra Prasad Bhandari ${ }^{1, b}$, Prem Timalsina $^{2, c}$ \\ ${ }^{1}$ Rainbow Trout Fishery Research Station, Dhunche, Rasuwa, Nepal \\ ${ }^{2}$ Fishery Research Division, Godawari, Lalitpur, Nepal
}

*Corresponding author

A R T I C L E I N F O A B S T R A C T

\section{Research Article}

Received : 05/05/2020 Accepted : 27/07/2020

Keywords:

Citric acid

Phytase

Total harvest weight

Feed conversion ratio

Specific growth rate

\begin{abstract}
Rainbow trout, a salmonid species has an economic importance worldwide and contributes to the indigenous food security. The present study was conducted in complete randomized design (CRD) to evaluate the dietary inclusion of citric acid with phytase as supplement on growth responses of rainbow trout. There were four treatments of diets with $0.5 \%$ citric acid (T1), $1 \%$ citric acid (T2), $1.5 \%$ citric acid (T3) and $0 \%$ control (T4) of citric acid incorporated with 1200FYT phytase as supplement. The treatments were replicated three times. Total harvest weight of fish in T3 $(5720.2 \pm 105.6 \mathrm{~g})$ was significantly higher and different than $\mathrm{T} 2 \quad(4595.9 \pm 434.9 \mathrm{~g}), \mathrm{T} 1$ $(4589.8 \pm 240.2 \mathrm{~g})$ and $\mathrm{T} 4(4567.5 \pm 217.3 \mathrm{~g})$. The highest daily growth rate was seen in treatment T3 $(1.1 \pm 0.0)$ which was significantly different than $\mathrm{T} 2(0.9 \pm 0.0), \mathrm{T} 1(0.9 \pm 0.0)$ and $\mathrm{T} 4(0.8 \pm 0.0)$. The highest specific growth rate was seen in the treatment T3 $(0.8 \pm 0.01)$ which was significantly different than $\mathrm{T} 1(0.7 \pm 0.0), \mathrm{T} 2(0.7 \pm 0.1)$ and $\mathrm{T} 4(0.7 \pm 0.0)$. The lowest food conversion ratio was seen in T3 $(2.2 \pm 0.1)$ which was significantly different with T2 $(2.6 \pm 0.1)$, T1 $(2.7 \pm 0.1)$ and T4 $(2.8 \pm 0.1)$. Similarly, the highest protein efficiency ratio was seen in treatment $\mathrm{T} 3(1.0 \pm 0.1)$ which was not significantly different with $\mathrm{T} 2(0.8 \pm 0.0)$ and $\mathrm{T} 1(0.8 \pm 0.1)$ but was significantly different than T4 $(0.7 \pm 0.0)$. No significant changes were observed in water temperature, dissolve oxygen and $\mathrm{pH}$ under different treatments. The present findings demonstrated that dietary inclusion of citric acid with phytase as supplement enhance growth by reducing the $\mathrm{pH}$ in the gut which increases the phytate hydrolysis, kills the pathogens, decreases the rate of gastric emptying, improves mineralization and nutrient absorption.
\end{abstract}

\section{Introduction}

Production of the aquaculture feed is anticipated to be heightened from 45 to 50,65 and 87 million metric tons from 2015, 2020 and 2025, respectively (Tacon and Metian, 2015). Sustainable commercial aquaculture requires fish meal replaced by plant or grain byproduct materials because fish meal is a finite resource (Sugiura et al., 2001). Soybean meal is considered a promising protein source because of its readily supply, high protein content and low phosphorus (P) content relative to fish meal (Hardy, 1995). However, about two-thirds of $P$ in soybean meal is present as phytate (inositol hexaphosphate) which is not efficiently utilized by fish (NRC, 1993). In addition, phytate interacts with trace minerals and protein, reducing their availability (NRC, 1993). Heat treatment may reduce phytate in plant feed ingredients (Hafez et al., 1989; Satoh et al., 1998) and the use of phytase is also effective (Cain and Garling, 1995; Rodehutscord and Pfeffer, 1995).

Chile, Denmark, France, Germany, Italy, Iran, Norway, Spain, the UK and the USA are the major countries producing the rainbow trout. The global production of rainbow trout amounted to 814,090 tons in 2016 (FAO, 2018). Rainbow trout, a salmonid species has an economic importance worldwide and contributes to the indigenous food security with annual production of 300 tons in 2016 thus establishing itself as one of the main cultured fish species in Nepal (FAEPD, 2012; FRD, 2017). The aim of the present research work was to discover easily available, environment friendly optimum levels of citric acid (CA) and phytase to fulfill the nutritional demands of fish species like Oncorhynchus mykiss. 


\section{Materials and Methods}

\section{Experimental Site and Design}

The experiment was carried out under controlled hatchery conditions at Rainbow Trout Fishery Research Station, Dhunche $\left(28.1080^{\circ} \mathrm{N}, 85.2891^{\circ} \mathrm{E}\right)$ located at the altitude of 1850 meter above sea level. Initially, about 1000 trout of $50 \mathrm{~g}$ size were maintained in two raceways. During the culture period of a week, the fishes were acclimatized by feeding control diet (commercial extruded trout feed of crude protein $34.9 \%$; crude lipid $1.17 \%$; crude fiber $4.98 \%$; total ash $16.99 \%$ ) at the rate of $3 \%$ of the body size in a flow-through raceway type. After acclimatization, 25 trout were netted from the raceways and transferred to each individual 12 outdoor raceways with flow-through system having water volume of $3.23 \mathrm{~m}^{3}(4.5 \mathrm{~m} \mathrm{x} 1.44 \mathrm{~m} \times 0.5 \mathrm{~m})$.

There were four treatments of diets with $0.5 \%$ citric acid (T1), $1 \%$ citric acid (T2), $1.5 \%$ citric acid (T3) and $0 \%$ of citric acid control (T4) incorporated with 1200FYT phytase as supplement. The treatments were replicated three times. The experiment was conducted for 180 days from August 31, 2018 to February 26, 2019. The randomization of treatments were done by creating random numbers in the MS Excel sheet using RAND ( ) command.

\section{Preparation of Pellet Diet}

Four diets with same levels of dietary protein (approximately 47\%) were formulated: - fish meal based diet (control) and $0.5 \%, 1 \%$ and $1.5 \%$ addition of citric acid as additives on total diet. To prepare formulated diet for the experiment, all ingredients (Table 1) were grounded thoroughly and sieved to pass through $0.5 \mathrm{~mm}$ mesh size; mixed together in a blender and then put into the electric operated pellet machine for the preparation of pellet diet of size $<3 \mathrm{~mm}$. The pellets were air dried and packed in plastic bags. At last they were stored at $4{ }^{\circ} \mathrm{C}$.

\section{Feeding}

Fishes were hand fed with pellet feed as suggested by the Rainbow trout daily feeding guide and adapted in accordance to the daily temperature and the total body weight in each raceway (Tacon, 1987). The total daily feed ration was divided into 2 equal portions and delivered at 10:00 AM and 4:00 PM under ambient lighting in first month and reduced to one delivered at 12:00 PM in later months.

\section{Sampling Protocol}

Monthly sampling was done of each raceway by seining. Ten fishes were randomly weighed by weighing balance $( \pm 0.1 \mathrm{~g}$, Phoenix instrument electronic balance, Model SN-014739) and its growth measurements were assessed.

\section{Determination of Growth Performance}

Growth in weight of the fish was expressed as daily growth rate (DGR) and specific growth rate (SGR). Similarly, survival rate (SR), feed conversion ratio (FCR), protein efficiency ratio (PER), gross fish yield (GFY) and net fish yield (NFY) were also calculated.

$$
\begin{aligned}
& \text { Weight gain }(\mathrm{WG})=(\text { wf-wi }) \\
& \text { DGR }(\mathrm{g} / \mathrm{fish} / \text { day })=(\text { wf-wi }) / \text { culture period }
\end{aligned}
$$

$\operatorname{SGR}(\%$ per day $)=((\ln (\mathrm{wf})-\ln ($ wi $) /$ culture period $) \times 100$ FCR $=$ Quantity of feed supplied $(\mathrm{kg}) /$ Net fish yield $(\mathrm{kg})$ $\mathrm{SR}(\%)=($ Total number of fish harvested/ Total number of fishes stocked) $\times 100$

PER = wet weight gain $(\mathrm{g}) /$ total protein intake $(\mathrm{g})$ GFY $($ ton/ha/cycle $)=($ wf $(\mathrm{kg}) / 1000) / 10000 \times$ Culture Days

$\mathrm{NFY}($ ton $/$ ha/cycle $)=((\mathrm{wf} \quad(\mathrm{kg})-\mathrm{wi}(\mathrm{kg})) / 1000) / 10000 \times$ Culture Days

Where, wi and wf are the initial and final mean wet body weights in gram, respectively.

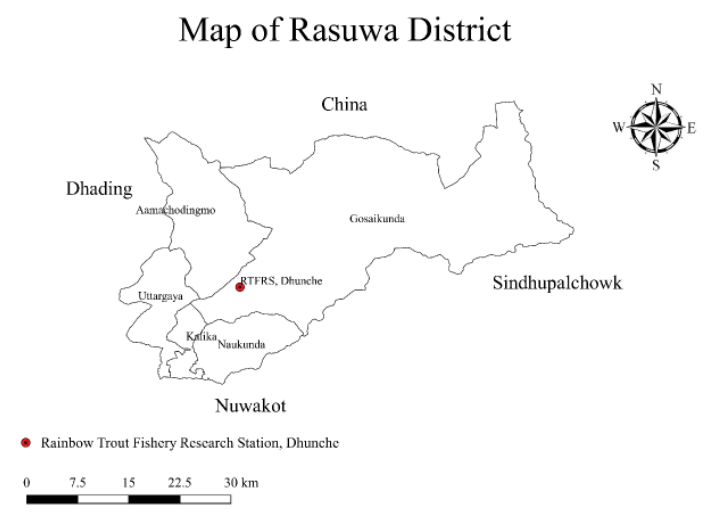

Figure 1. Administrative map showing location of the field experiment in Rasuwa district, Nepal.

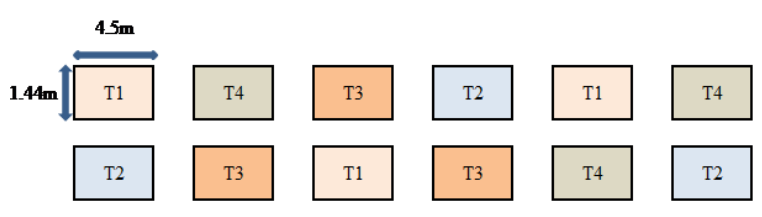

Figure 2. Layout and geometry of the experimental raceways.

Table 1. Ingredients and composition, percentage of the experimental diet.

\begin{tabular}{l|cccc}
\hline \multirow{2}{*}{\multicolumn{1}{c}{ Ingredient }} & \multicolumn{3}{c}{ Treatments } & Control \\
\cline { 2 - 5 } & T1 & T2 & T3 & T4 \\
\hline Jwala (Small Shrimp) & 51.3 & 51.3 & 51.3 & 51.3 \\
Soya full roasted & 35.0 & 35.0 & 35.0 & 35.0 \\
Wheat grain & 10.7 & 10.7 & 10.7 & 10.7 \\
\hline \multicolumn{5}{c}{ Additional } \\
\hline Vitamin premix* & 2.0 & 2.0 & 2.0 & 2.0 \\
Mineral mix** & 2.0 & 2.0 & 2.0 & 2.0 \\
Liver tonic & 3.0 & 3.0 & 3.0 & 3.0 \\
Yeast & 1.0 & 1.0 & 1.0 & 1.0 \\
Salt & 1.0 & 1.0 & 1.0 & 1.0 \\
\hline \multicolumn{5}{|c}{ Additives } \\
Citric Acid (\%) & 0.5 & 1.0 & 1.5 & 0.0 \\
Phytase (FYT) & 1200.0 & 1200.0 & 1200.0 & 1200.0 \\
\hline
\end{tabular}

*Vitamin mixture/kg premix containing the following: 33000IU vitamin A, 3300IU, vitamin D3, 410IU vitamin E, 2660mg Vitamin BI, 133mg vitamin B2, 580mg vitamin B6, 41 mg vitamin B12, 50mg biotin, 9330mg choline chloride, $4000 \mathrm{mg}$ vitamin C, $2660 \mathrm{mg}$ Inositol, 330mg para-amino benzoic acid, $9330 \mathrm{mg}$ niacin, $26.60 \mathrm{mg}$ pantothenic acid, **Mineral mixture/kg premix containing the following: 325mg Manganese, $200 \mathrm{mg}$ Iron, 25mg Copper, 5mg Iodine, 5mg Cobalt 


\section{Water Quality Analysis}

Temperature was measured at daily intervals at out flow of each raceway and dissolved oxygen (DO), $\mathrm{pH}$ was measured fortnightly. Portable $\mathrm{pH}$ meter by ThermosElectron Corporation Russell 060p was used to monitor $\mathrm{pH}$ and Temperature was measured using digital thermometer. Similarly, Orion 5 star S.N. 005840 by Thermo-Electron Corporation, U.S.A., was used to monitor dissolve oxygen. Temperature in degree centigrade $\left({ }^{\circ} \mathrm{C}\right)$ and dissolve oxygen in parts per million $(\mathrm{mg} / \mathrm{L})$ was noted for each value monitored.

\section{Harvesting}

Final harvesting of rainbow trout was done after 180 days on the termination of the research. Harvested fish was measured using electronic balance. Fishes were counted and their batch weight was recorded.

\section{Statistical Analysis}

The data were collected during the course of time and on the basis of individual fish observations, the population means for each character was computed. The analysis of variance was used to compare different growth parameters and water quality parameters using R-Stat (version 3.6.3). The mean and standard errors were calculated for each treatment. The data entry was done through MS Excel 2016. The accepted level of significance was $p<0.05$.

\section{Results}

The total stock weight, total harvest weight, survivability, daily growth rate, specific growth rate, food conversion ratio and protein efficiency ratio of fish in different treatments are presented in Table 2.

A mean weight of about $52.3 \pm 0.3 \mathrm{~g}$ size fry were stocked at the beginning of experiment in all treatments which were not significantly different with each other $(\mathrm{P}>0.05)$. The stocking number of fishes were 25 per raceway. Result showed that there was no significant difference in survival rates of fishes among the treatments.
At the end of the experiment weight gain (WG) of fish in T3 $(4408.5 \pm 105.9 \mathrm{~g})$ was significantly $(\mathrm{P}<0.05)$ higher than T1 (3293.9 $\pm 231.6 \mathrm{~g}), \quad \mathrm{T} 2 \quad(3293.4 \pm 424.2 \mathrm{~g})$ and T4 $(3245.8 \pm 218.5 \mathrm{~g})$, while $\mathrm{T} 1, \mathrm{~T} 2$ and $\mathrm{T} 4$ were not significantly different with each other.

In a like manner, there was a significant difference $(\mathrm{P}<0.05)$ in specific growth rate $(\mathrm{SGR}, \% /$ day) of different treatments. The highest SGR was seen in T3 $(0.8 \pm 0.0)$ which was significantly different with $\mathrm{T} 1(0.7 \pm 0.0)$, T2 $(0.7 \pm 0.1)$ and $\mathrm{T} 4(0.7 \pm 0.0)$ at $(\mathrm{P}<0.05)$ and remaining treatments were not significantly different with each other $(\mathrm{P}>0.05)$. The DGR was also highest in T3 $(1.1 \pm 0.0 \mathrm{~g} /$ day $)$ which was significantly different $(\mathrm{P}<0.05)$ with $\mathrm{T} 1$ $(0.9 \pm 0.0 \mathrm{~g} /$ day $), \mathrm{T} 2(0.9 \pm 0.0 \mathrm{~g} /$ day $)$ and T4 $(0.8 \pm 0.0 \mathrm{~g} /$ day $)$. The treatment $\mathrm{T} 1$ was not significantly different with $\mathrm{T} 2$ and $\mathrm{T} 4$ but these were significantly different with each other $(\mathrm{P}<0.05)$.

Significant differences in FCR and protein efficiency ratio (PER) were observed among treatments during the study period $(\mathrm{P}<0.05)$. The lowest $\mathrm{FCR}$ was seen in $\mathrm{T} 3$ $(2.2 \pm 0.1)$ which was significantly different $(\mathrm{P}<0.05)$ with T2 (2.6 \pm 0.1$)$, T1 (2.7 \pm 0.1$)$ and T4 (2.8 \pm 0.1$)$. However, T2 was also not significantly different with $\mathrm{T} 1(\mathrm{P}>0.05)$ but both were significantly different $(\mathrm{P}<0.05)$ with $\mathrm{T} 4$. Similarly, the highest PER was seen in T3 $(1.0 \pm 0.1)$ which was not significantly different with T2 $(0.8 \pm 0.0)$ and T1 $(0.8 \pm 0.1)(\mathrm{P}>0.05)$ but was significantly different than $\mathrm{T} 4$ $(0.7 \pm 0.0) \quad(\mathrm{P}<0.05)$. Similarly, $\mathrm{T} 1$ and $\mathrm{T} 2$ was not significantly different $(\mathrm{P}>0.05)$ with $\mathrm{T} 4$.

Mean gross yield (ton/ha/cycle) and Net yield (ton/ha/cycle) of fishes during experimental period are presented in Table 3. The mean gross fish yield of T3 (51.5 \pm 1.0$)$ was higher than T2 (41.4 \pm 3.9$), \mathrm{T} 1$ (41.3 \pm 2.2$)$ and T4 (41.1 \pm 1.9$)$ and was highly significantly different $(\mathrm{P}<0.05)$. However, T1, T2 and T4 were not significantly different with each other $(\mathrm{P}>0.05)$. Similarly, net fish yield of T3 (39.7 \pm 0.9$)$ was significantly higher with T1 (29.7 \pm 2.1$)$, T2 (29.6 \pm 3.8$)$ and T4 (29.1 \pm 1.9$)$ while T1, T2 and T4 were not significantly different with each other as presented in Table $3(\mathrm{P}>0.05)$.

Table 2. Mean value of growth parameters of rainbow trout during experimental period of 180 days. All data presented are for $3.23 \mathrm{~m}^{3}$ raceways.

\begin{tabular}{|c|c|c|c|c|}
\hline \multirow{2}{*}{ Growth parameters } & \multicolumn{3}{|c|}{ Treatments (Mean \pm S.E.) } & \multirow{2}{*}{$\begin{array}{c}\text { Control } \\
\mathrm{T} 4\end{array}$} \\
\hline & $\mathrm{T} 1$ & $\mathrm{~T} 2$ & T3 & \\
\hline Total stock weight $(\mathrm{g})$ & $1295.8 \pm 8.7$ & $1302.5 \pm 13.2$ & $1311.7 \pm 4.6$ & $1321.7 \pm 3.0$ \\
\hline Total harvest weight (g) & $4589.8 \pm 240.2^{\mathrm{b}}$ & $4595.9 \pm 434.9^{\mathrm{b}}$ & $5720.2 \pm 105.6^{\mathrm{a}}$ & $4567.5 \pm 217.3^{b}$ \\
\hline Weight Gain (WG) & $3293.9 \pm 231.6^{\mathrm{b}}$ & $3293.4 \pm 424.2^{\mathrm{b}}$ & $4408.5 \pm 105.9^{\mathrm{a}}$ & $3245.8 \pm 218.5^{\mathrm{b}}$ \\
\hline Survival (\%) & $88 \pm 4.6$ & $84 \pm 8.0$ & $91 \pm 1.3$ & $92 \pm 4.6$ \\
\hline Daily growth rate (DGR) & $0.9 \pm 0.0^{\mathrm{bc}}$ & $0.9 \pm 0.0^{\mathrm{b}}$ & $1.1 \pm 0.0^{\mathrm{a}}$ & $0.8 \pm 0.0^{\mathrm{c}}$ \\
\hline Specific growth rate (SGR) & $0.7 \pm 0.0^{\mathrm{b}}$ & $0.7 \pm 0.1^{\mathrm{b}}$ & $0.8 \pm 0.0^{\mathrm{a}}$ & $0.7 \pm 0.0^{\mathrm{b}}$ \\
\hline Food conversion ratio (FCR) & $2.7 \pm 0.1^{\mathrm{b}}$ & $2.6 \pm 0.1^{b}$ & $2.2 \pm 0.1^{\mathrm{c}}$ & $2.8 \pm 0.1^{\mathrm{a}}$ \\
\hline Protein efficiency ratio (PER) & $0.8 \pm 0.1^{\mathrm{ab}}$ & $0.8 \pm 0.0^{\mathrm{ab}}$ & $1.0 \pm 0.1^{\mathrm{a}}$ & $0.7 \pm 0.0^{\mathrm{b}}$ \\
\hline
\end{tabular}

$\mathrm{T} 1=0.5 \%$ Citric acid Diet 1; T2=1\% Citric acid Diet 2; T3=1.5\% Citric acid Diet 3 and T4= Control Diet 4. Mean value with different superscript letter within same row are significantly different at $\mathrm{P}<0.05$.

Table 3. Mean value of extrapolated yield parameters of rainbow trout during experimental period of 180 days.

\begin{tabular}{l|cccc}
\hline \multirow{2}{*}{ Yield parameters } & \multicolumn{3}{|c}{ Treatments (Mean \pm S.E.) } & Control \\
\cline { 2 - 4 } & $\mathrm{T} 1$ & $\mathrm{~T} 2$ & $\mathrm{~T} 3$ & \\
\hline Gross fish yield (ton/ha/cycle) & $41.3 \pm 2.2^{\mathrm{b}}$ & $41.4 \pm 3.9^{\mathrm{b}}$ & $51.5 \pm 0.9^{\mathrm{a}}$ & $41.1 \pm 1.9^{\mathrm{b}}$ \\
Net fish yield (ton/ha/cycle) & $29.7 \pm 2.1^{\mathrm{b}}$ & $29.6 \pm 3.8^{\mathrm{b}}$ & $39.7 \pm 0.9^{\mathrm{a}}$ & $29.1 \pm 1.9^{\mathrm{b}}$ \\
\hline
\end{tabular}

$\mathrm{T} 1=0.5 \%$ Citric acid Diet 1; T2=1\% Citric acid Diet 2; T3=1.5\% Citric acid Diet 3 and T4= Control Diet 4 . Mean value with different superscript letter within same row are significantly different at $\mathrm{P}<0.05$. 
Table 4. Values of water quality parameters Temperature $\left({ }^{\circ} \mathrm{C}\right)$ measured daily and dissolve oxygen $(\mathrm{mg} / \mathrm{L})$ and $\mathrm{pH}$ measured fortnightly during experimental period of 180 days.

\begin{tabular}{l|cccc}
\hline \multirow{2}{*}{ Water quality parameters } & \multicolumn{3}{|c}{ Treatment (Mean \pm S.E.) } & Control \\
\cline { 2 - 4 } & $\mathrm{T} 1$ & $\mathrm{~T} 2$ & $\mathrm{~T} 3$ & $\mathrm{~T} 4$ \\
\hline Temperature $\left({ }^{\circ} \mathrm{C}\right)$ & $18.5 \pm 0.1(18.3-18.9)$ & $18.6 \pm 0.1(18.4-19.6)$ & $18.2 \pm 0.1(18.2-19.1)$ & $18.9 \pm 0.1(18.6-19.3)$ \\
Dissolve Oxygen $(\mathrm{mg} / \mathrm{L})$ & $8.6 \pm 0.1(8.5-8.9)$ & $8.5 \pm 0.1(8.3-8.6)$ & $8.6 \pm 0.1(8.4-8.8)$ & $8.5 \pm 0.2(8.0-8.9)$ \\
$\mathrm{pH}$ & $8.5 \pm 0.1(8.4-8.7)$ & $8.3 \pm 0.1(8.1-8.5)$ & $8.4 \pm 0.1(8.2-8.5)$ & $8.4 \pm 0.1(8.2-8.5)$ \\
\hline \multicolumn{2}{l}{$\mathrm{T} 1=0.5 \%$ Citric acid Diet $1 ; \mathrm{T} 2=1 \%$ Citric acid Diet 2; T3= 1.5\% Citric acid Diet 3 and T4= Control Diet 4. Mean value with different superscript }
\end{tabular}

$\mathrm{T} 1=0.5 \%$ Citric acid Diet $1 ; \mathrm{T} 2=1 \%$ Citric acid Diet 2; T3=1.5\% Citric acid Diet 3 and T4= Control Diet 4 . Mean value with different superscript letter within same row are significantly different at $\mathrm{P}<0.05$.

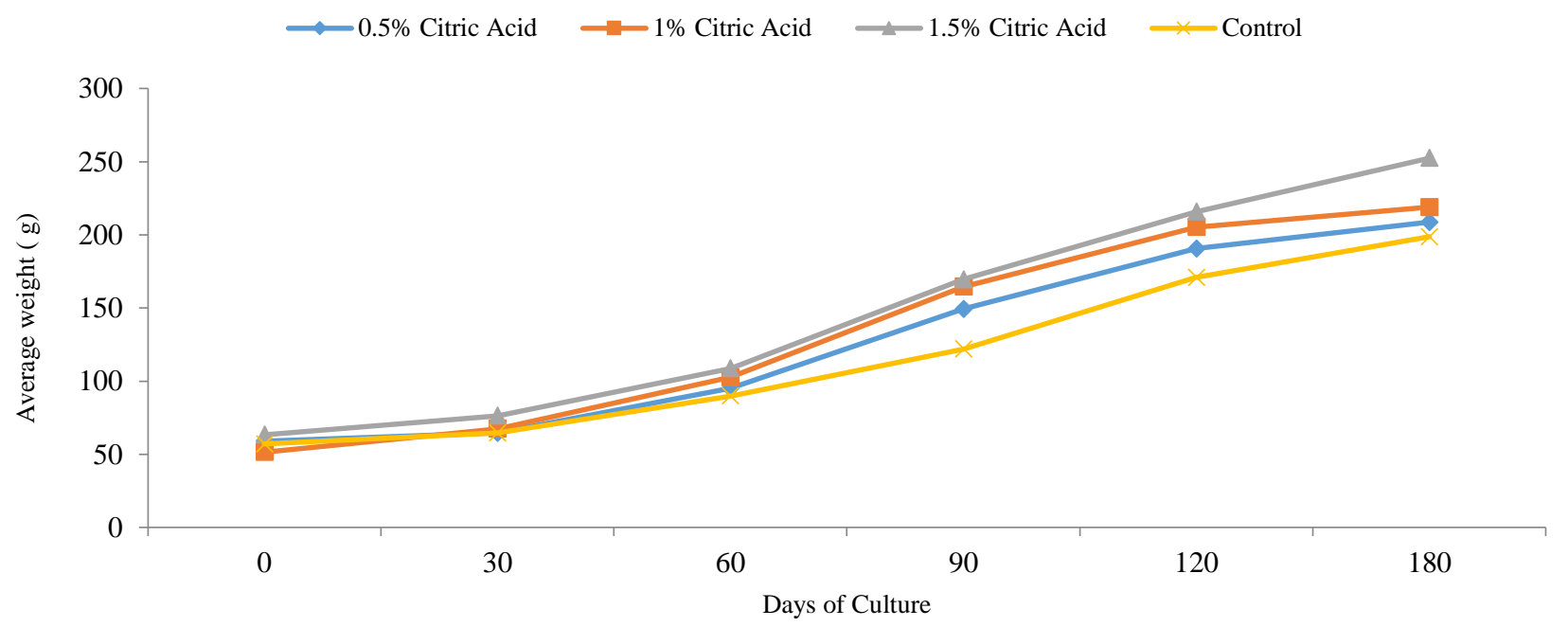

Figure 3. Growth trends of rainbow trout fry in different treatments during experimental period of 180 days. T1 $=0.5 \%$ Citric acid Diet 1; T2=1\% Citric acid Diet 2; T3=1.5\% Citric acid Diet 3 and T4= Control Diet 4.

The monthly growth trend of rainbow trout fry during the experimental period is illustrated in Figure 3. The fries grew steadily until 60 days of culture and exponentially from then after up to 180 days.

Mean and range of temperature were measured daily whereas $\mathrm{pH}$ and dissolved oxygen of water were measured fortnightly during experimental period which are represented in the Table 4. Water quality during the experimental period was found at desired level. Parameters like temperature, $\mathrm{pH}$ and dissolved oxygen were not significantly different $(\mathrm{P}>0.05)$ among treatments.

\section{Discussion}

In the present study citric acid and phytase significantly affected the digestibility of nutrients in O. mykiss diets. Acidification of diet with $1.5 \%$ citric acid significantly improved the apparent digestibility of phosphorus in $O$. mykiss diets which was also observed in rainbow trout (Sugiura et al., 2001) and broiler (Hariharan and Gangadevi, 2015) which showed improvement in mineral utilization. At 3\% citric acid, Beluga (Husso huso) exhibit comparable improvements (Khajepour and Hosseini, 2010, 2012), L. rohita (Baruah et al., 2005), 5\% and 1\% citric acid in O. mykiss (Sugiura et al., 2001; Hernandez et al., 2012), 2\% acidifications in tiger shrimp (Ng et al., 2011), $4 \%$ acidifications in white shrimp (Romano et al., 2015) and $1 \%$ acidification in pigs (Boling et al., 2000). Phytate phosphorus remain unavailable to fish owing to the absence of enzyme in stomach of fish (NRC, 1983) as Phytate is the principal anti-nutritional factor in diets based on crops which binds minerals (Satoh et al., 1998). Enzymatic breakdown of phytate by phytase may increase the retention and availability of phosphorus (Cao et al., 2007; Morales et al., 2014).

Addition of citric acid in the diet increased the weight gain, SGR, PER and reduced the FCR of the trout in the present study. Similar findings were observed by Wang et al. (2009) in rainbow trout, Baruah et al. (2007) in Labeo rohita, Bano and Afzal (2017) in L. rohita and Taheri and Taherkhani (2015) in broiler. The beneficial effect of citric acid could possibly be due to the release of minerals from the phytic acid complex (Sugiura et al., 1998; Boiling et al., 2000; Brenes et al., 2003). Sarker et al. (2005) reported an increase in the growth performance of red sea bream, Pagrus major, fed with citric acid-supplemented diet. Similar observations had also been reported in pigs and chicks (Kornegay et al., 1994; Boiling et al., 2000; Jongbloed et al., 2000). Supplementation of microbial phytase in the diets with citric acid had a positive effect on the growth performance of rainbow trout similar to the study of Vielma et al. (2002) and Yoo et al. (2005) in Korean rockfish. The improvement in growth performance in the present study was related to improved utilization of phytate-P. Many authors Lei et al. (1993) in pigs; Liebert and Portz (2005) in Nile tilapia and Debnath et al. (2005) in $P$. pangasius also observed an improvement in growth performance in different animals with phytase supplementation. The growth performance in our present was the highest in groups fed with diets containing $1.5 \%$ citric acid and 1200 FYT microbial phytase, showing their synergistic effect. This may be explained by the lower $\mathrm{pH}$ 
of intestinal digesta due to the addition of citric acid (Radcliffe et al., 1998; Baruah et al., 2005), which in turn enhances the efficacy of microbial phytase (Kemme et al., 1995).

Net fish yield (ton/ha/cycle), of treatment T3 was higher compared to $\mathrm{T} 1, \mathrm{~T} 2$ and $\mathrm{T} 4$ which were not significantly different to each other. This might be due to lack of grading throughout study period and grading fish fry is essential for uniform growth and cannibalism (Rai et al., 2008). The monthly growth trend of rainbow trout fry shows that fry grew steadily until 60 days of culture and exponentially from then after up to 180 days. Similar result was observed by Wagner et al. (1996) in rainbow trout fry and Pandit and Nakamura (2010) in Nile tilapia fry. No significant changes were observed in water temperature $\left({ }^{\circ} \mathrm{C}\right)$, dissolve oxygen $(\mathrm{mg} / \mathrm{L})$ and $\mathrm{pH}$ under different treatments.

In conclusion, despite the limited literature on the use of citric acid in fish feed, the results from the available studies indicate that citric acid has promising potential to improve growth and feed performance in fish. It enhanced growth by reducing the $\mathrm{pH}$ in the gut which increases the phytate hydrolysis, kills the pathogens, decreases the rate of gastric emptying and improves mineralization and nutrient absorption. Its acidification with phytase supplementation in fish feed can efficiently be used to formulate cost effective and environment friendly feed.

\section{Acknowledgements}

The authors are thankful to the Nepal Agriculture Research Council for providing the budget necessary for conducting this research. We would also like to thank Mrs. Neeta Pradhan for her advisory as well as technical support. In last, we would like to thank team of Rainbow Trout Fishery Research Station for overall support during the research period.

\section{References}

Bano N, Afzal M. 2018. Synchronized effect of citric acid and phytase supplementation on growth performance and nutrient digestibility of Labeo rohita. Aquaculture Nutrition, 24(2): 786-792.

Baruah K, Pal AK, Sahu NP, Jain KK, Mukherjee SC, Debnath D. 2005. Dietary protein level, microbial phytase, citric acid and their interactions on bone mineralization of Labeo rohita (Hamilton) juveniles. Aquaculture Research, 36: 803-812.

Baruah K, Sahu NP, Pal AK, Jain KK, Debnath D, Mukherjee SC. 2007. Dietary microbial phytase and citric acid synergistically enhances nutrient digestibility and growth performance of Labeo rohita (Hamilton) juveniles at suboptimal protein level. Aquaculture Research, 38: 109-120

Boiling SD, Webel DM, Mavromichalis I, Parsons CM, Baker DH. 2000. The effects of citric acid on phytate-phosphorus utilization in young chicks and pigs. Journal of Animal Science, 78: 682-689.

Brenes A, Viveros A, Arija I, Centeno C, Pizzaro M, Bravo C. 2003. The effect of citric acid and microbial phytase on mineral utilization in broiler chicks. Animal Feed Science and Technology, 110: 201-219.

Cain KD, Garling DL. 1995. Pretreatment of soybean meal with phytase for salmonid diets to reduce phosphorus concentrations in hatchery effluents. The Progressive FishCulturist, 57(2): 114-119.
Cao L, Wang WM, Yang CT, Yang Y, Diana J, Yakupitiyage A, Luo Z, Li DP. 2007. Application of microbial phytase in fish feed. Enzyme and Microbial Technology, 40: 497-507.

Debnath D, Pal AK, Sahu NP, Jain KK, Yengkokpam S, Mukherjee SC. 2005. Effect of dietary microbial phytase supplementation on growth and nutrient digestibility of Pangasius pangasius (Hamilton) fingerlings. Aquaculture Research, 36: 180-187.

FAO, 2018. The state of world fisheries and aquaculture, meeting the sustainable development goals. Food and Agriculture Organization of the United Nations. 23.

FAEPD, 2012. The State of World Fisheries and Aquaculture 2012. Fishery and Aquaculture Economics and Policy Division Rome: FAO. Retrieved from: www.fao.org/3/ai2727e.pdf

FRD, 2017. Annual Report 2071/72 (2014/15). Fisheries Research Division NARC, Godawari, Lalitpur, Nepal.

Hafez YS, Mohammed AI, Perera PA, Singh G, Hussein AS. 1989. Effects of microwave heating and gamma irradiation on phytate and phospholipid contents of soybean (Glycine max L.). Journal of Food Science, 54(4): 958-962.

Hardy RW. 1995. Current issues in salmonid nutrition. In: Nutrition and Utilization Technology in Aquaculture (ed. by C. Lim \& D.J. Sessa), 26-35. AOCS Press, Campaign, IL, USA. 26-35.

Hariharan T, Gangadevi P. 2015. Efficacy of citric acid and microbial phytase on the tibial characteristics, tibial and serum mineral concentration in broiler chicken. Indian Journal of Animal Research, 49: 328-332.

Hernández AJ, Satoh S, Kiron V. 2012. Supplementation of citric acid and amino acid chelated trace elements in low-fish meal diet for rainbow trout affect growth and phosphorus utilization. Journal of the World Aquaculture Society, 43: 688-696.

Jongbloed AW, Mroz Z, van der Weij-Jongblloed R, Kemme PA. 2000. The effects of microbial phytase, organic acids and their interaction in diets for growing pigs. Livestock Production Science, 67: 113-122.

Kemme PA, Jongbloed AW, Mroz Z, Makinen, M. 1995. Apparent ileal amino acid digestibility in pigs as affected by phytate, microbial phytase, and lactic acid. Journal of Animal Science, 73: 173.

Khajepour F, Hosseini SA. 2010. Mineral status of juvenile beluga (Huso huso) fed citric acid supplemented diets. World Applied Sciences Journal, 11: 682-686.

Khajepour F, Hosseini SA. 2012. Calcium and phosphorus status in juvenile Beluga (Huso huso) fed citric acid-supplemented diets. Aquaculture Research, 43: 407-411.

Kornegay ET, Evans JL, Ravindran V. 1994. The effect of diet acidity and protein level or source of calcium on the performance, gastrointestinal content measurements, bone measurements and carcass composition of gilt and Barrow weanling pigs. Journal of Animal Science, 72: 2670-2680.

Lei XG, Ku PK, Miller ER, Yokoyama MT, Ullrey DE. 1993. Supplementing corn-soybean meal diets with microbial phytase maximizes phytate $\mathrm{P}$ utilization by weanling pigs. Journal of Animal Science, 71: 3368-3375.

Liebert F, Portz L. 2005. Nutrient utilization of Nile tilapia Oreochromis niloticus fed plant based low phosphorus diets supplemented with graded levels of different sources of microbial phytase. Aquaculture, 248(1-4): 111-119.

Morales GA, Marquez L, Rodriganez MSD, Bermudez L, Robles R, Moyano FJ. 2014. Effect of phytase supplementation of a plant-based diet on phosphorus and nitrogen bioavailability in sea bream Sparus aurata. Aquaculture Nutrition, 20: 172182.

Ng K, Cheng-Fang L, Chandana PS, Pui-Kwan AH, Ping-Yi Y. 2011. Reduced membrane fouling in a novel bio-entrapped membrane reactor for treatment of food and Beverage processing wastewater. Water Research, 45: 4269-4278. 
NRC, 1983. Nutrient requirements of cold water fishes and shellfishes. National Academy Press, Washington, DC, 63.

NRC, 1993. Nutrient Requirements of Fish. National Academy Press, Washington, DC, 45.

Pandit NP, Nakamura M. 2010. Effect of High Temperature on Survival, Growth and Feed Conversion Ratio of Nile Tilapia, Oreochromis niloticus. Our Nature, 8(1): 219-224.

Radcliffe JS, Zhang Z, Kornegay ET. 1998. The effects of microbial phytase, citric acid and their interaction in a cornsoybean meal-based diet for weanling pigs. Journal of Animal Science, 76: 1880-1886.

Rai AK, Gurung TB, Basnet SR, Mulmi RM. 2008. Present Status and Prospect of Rainbow Trout (Oncorhynchus mykiss) Farming in Nepal. In: T.B. Gurung (ed.) Proceedings of the workshop on "Rainbow trout farming scaling-up strategies in Nepal". 25-30.

Rodehutscord M, Pfeffer E. 1995. Effects of supplemental microbial phytase on phosphorus digestibility and utilization in rainbow trout (Oncorhynchus mykiss). Water Science and Technology, 31(10): 143-147.

Romano N, Koh C, Ng W. 2015. Dietary microencapsulated organic acid blend enhances growth, phosphorus utilization, immune response, hepatopancreatic integrity and resistance against Vibrio harveyi in white shrimp, Litopenaeus vannamei. Aquaculture, 435: 228-236.

Sarker SA, Satoh S, Kiron V. 2005. Supplementation of citric acid and amino acid-chelated trace element to develop environment-friendly feed for red sea bream, Pagrus major. Aquaculture, 48: 3-11.

Satoh S, Higgs DA, Dosanjh BS, Hardy RW, Eales JG, Deacon G. 1998. Effect of extrusion processing on the nutritive value of canola meal for Chinook salmon (Oncorhynchus tshawytscha) in seawater. Aquaculture Nutrition, 4: 115-122.
Sugiura SH, Dong FM, Hardy RW. 1998. Effect of dietary supplements on the availability of minerals in fishmeal: preliminary observation. Aquaculture, 160: 283-303.

Sugiura SH, Gabaudan J, Dong FM, Hardy RW. 2001. Dietary microbial phytase supplementation and the utilization of phosphorus, trace minerals and protein by rainbow trout (Oncorhynchus mykiss) fed soybean meal-based diets. Aquaculture Research, 32(7): 583-592.

Tacon AG. 1987. The nutrition and feeding of farmed fish and shrimp a training manual: the essential nutrients (No. 639.2085T32). FAO.

Tacon AG, Metian M. 2015. Feed matters: satisfying the feed demand of aquaculture. Reviews in Fisheries Science \& Aquaculture, 23(1): 1-10.

Taheri HR, Taherkhani S. 2015. Effect of phytase super doses and citric acid on growth performance, plasma phosphorus and tibia ash in broilers fed canola meal-based diets severely limited in available phosphorus. Poultry Science, 3: 27-36.

Vielma J, Ruohonen K, Peisker M. 2002. Dephytinization of two soy proteins increases phosphorus and protein utilization by rainbow trout, Oncorhynchus mykiss. Aquaculture, 204: 145156.

Wagner EJ, Intelmann SS, Routledge MD. 1996. The Effects of Fry Rearing Density on Hatchery Performance, Fin Condition, and Agonistic Behavior of Rainbow Trout Oncorhynchus mykiss Fry. Journal of the World Aquaculture Society, 27(3): 264-274.

Yoo GY, Wang X, Choi S, Han K, Kang JC, Bai SC. 2005. Dietary microbial phytase increased the phosphorus digestibility in juvenile Korean rockfish, Sebastes schlegeli fed diets containing soybean meal. Aquaculture, 243: 315322. 